\title{
Profil Kemampuan Pemecahan Masalah Matematika Siswa Berbentuk Soal Cerita Materi Bangun Ruang
}

\author{
Elya Umi Ani ${ }^{1}$, Puji Rahayu ${ }^{2}$ \\ ${ }^{1} J 1$. Manunggal 61 Tuban,elyaumiani27@yahoo.com \\ ${ }^{2}$ Jl. Manunggal 61 Tuban, pujirahayumpd@gmail.com
}

\begin{abstract}
ABSTRAK
Penelitian ini bertujuan untuk mendeskripsikan profil kemampuan pemecahan masalah berbentuk soal cerita pada materi bangun ruang. Jenis penelitian ini adalah penelitian deskriptif kualitatif. Subyek penelitian ini terdiri dari 6 siswa dengan kriteria 2 berkemampuan tinggi, 2 berkemampuan sedang dan 2 berkemampuan rendah. Hasil penelitian menunjukkan bahwa subyek berkemampuan tinggi dalam memecahkan masalah termasuk kategori baik, subyek berkemampuan sedang dalam memecahkan masalah termasuk dalam kategori cukup, dan subyek berkemampuan rendah dalam memecahkan masalah termasuk dalam kategori kurang.
\end{abstract}

Kata kunci: bangun ruang, kemampuan pemecahan masalah, soal cerita

\begin{abstract}
This study aimed to describe the student's profile of problem-solving skills in geometry story problems. This research is a qualitative descriptive study. The subjects of this study were six students who consisted of student with high ability, 2 student with medium ability and 2 student with low ability. The result showed that subject with high ability in solving problem included in the high category.The subjects with medium ability, in solving problem included in the quite category and the subject with low ability, in solving problem included in the poor category.
\end{abstract}

Keywords: geometry, problem solving skills, story problems

\section{Pendahuluan}

Matematika merupakan salah satu pelajaran yang harus ada dalam pendidikan, karena Matematika merupakan pembelajaran yang sangat penting dalam mengembangkan kemampuan matematis siswa. Hal ini sejalan dengan tujuan pembelajaran matematika yang dirumuskan Kurikulum Tingkat Satuan Pendidikan. Depdiknas : 2006 (dalam Saepuloh : 2013) menyatakan bahwa mata pelajaran matematika bertujuan agar peserta didik memiliki kemampuan sebagai berikut:

1. Memahami konsep matematika, menjelaskan keterkaitan antar konsep dan mengaplikasikan konsep atau algoritma, secara luwes, akurat, efisien, dan tepat dalam pemecahan masalah.

2. Menggunakan penalaran pada pola dan sifat, melakukan manipulasi matematika dalam membuat generalisasi, menyusun bukti, atau menjelaskan gagasan dan pernyataan matematika. 
3. Memecahkan masalah yang meliputi kemampuan memahami masalah, merancang model matematika, menyelesaikan model dan menafsirkan solusi yang diperoleh.

4. Mengkomunikasikan gagasan dengan symbol, tabel, diagram atau media lain untuk memperjelas keadaan atau masalah.

5. Memiliki sikap menghargai kegunaan matematika dalam kehidupan, yaitu memiliki rasa ingin tahu, perhatian, dan minat dalam mempelajari matematika, serta sikap ulet dan percaya diri dalam pemecahan masalah.

Sejalan dengan hal diatas, salah satu kemampuan yang harus dimiliki oleh siswa yaitu kemampuan dalam memecahkan masalah. Dalam memecahkan masalah siswa memiliki kemampuan yang berbeda-beda sebagaimana yang peneliti temukan di MTs Miftahul Ulum Magersari pada kelas VIII-B. Berdasarkan observasi yang dilakukan oleh peneliti di MTs Miftahul Ulum Magersari pada kelas VIII-B bahwa kemampuan dalam memecahkan masalah matematika khususnya pada soal cerita berbeda-beda. Hanya sebagian saja yang memiliki kemampuan yang baik dalam memecahkan masalah matematika. Banyak siswa yang masih kesulitan dalam memecahkan masalah baik dalam memahami masalah maupun merencanakan penyelesaian. Selain itu, kurang telitinya siswa juga dapat menyebabkan nilai siswa tersebut kurang memuaskan.

Kemampuan pemecahan masalah merupakan proses dimana siswa dapat menemukan berbagai cara menyelesaikan permasalahan yang diberika oleh gurunya. Menurut Anisa (2014) kemampuan pemecahan masalah adalah usaha atau cara siswa dalam menyelesaikan persoalan dengan menggunakan langkah-langkah sistematis. Menurut Polya : 1985 (dalam Sahrudin:2016) mengartikan bahwa pemecahan masalah sebagai suatu usaha mencari jalan keluar dari suatu kesulitan. Berdasarkan uraian diatas, kemampuan pemecahan masalah adalah suatu kesanggupan seseorang dalam melakukan suatu usaha untuk mencari jalan keluar terhadap masalah yang dihadapi.

Menurut Polya : 1973 (Rofiqoh :2015) dalam pemecahan masalah terdapat empat langkah yang harus dilakukan yaitu sebagai berikut: (a) Memahami masalah (understand the problem), (b) Merencanakan pemecahan (devising a plan), (c) Melaksanakan rencana (carry out a plan)dan, (d) Memeriksa kembali pemecahan yang diperoleh.(looking back at the complete solution).

Berikut adalah indikator kemampuan pemecahan masalah berdasarkan tahap pemecahan masalah oleh oleh polya.

TABEL 1 Indikator Kemampuan Pemecahan Masalah Berdasarkan Tahap Pemecahan Masalah Oleh Polya.

\begin{tabular}{|l|l|}
\hline \multicolumn{1}{|c|}{$\begin{array}{c}\text { Tahap Pemecahan } \\
\text { Masalah Oleh Polya }\end{array}$} & \multicolumn{1}{|c|}{ Indikator } \\
\hline Memahami masalah & $\begin{array}{l}\text { Siswa dapat menyebutkan informasi-informasi yang } \\
\text { diberikan dan pertanyaan yang diajukan }\end{array}$ \\
\hline $\begin{array}{l}\text { Merencanakan } \\
\text { Pemecahan }\end{array}$ & $\begin{array}{l}\text { Siswa memiliki rencana pemecahan masalah yang ia } \\
\text { gunakan serta alas an penggunaannya }\end{array}$ \\
\hline $\begin{array}{l}\text { Melakukan rencana } \\
\text { pemecahan }\end{array}$ & $\begin{array}{l}\text { Siswa dapat memecahkan masalah sesuai langkah- } \\
\text { langkah pemecahan masalah yang ia gunakan dengan } \\
\text { hasil yang benar }\end{array}$ \\
\hline $\begin{array}{l}\text { Memeriksa kembali } \\
\text { pemecahan }\end{array}$ & $\begin{array}{l}\text { Siswa memeriksa kembali langkah pemecahan } \\
\text { masalah yang ia gunakan. }\end{array}$ \\
\hline
\end{tabular}

Nirmalitasari (2012) 
Adapun masalah yang akan dipecahkan dalam penelitian ini adalah masalah matematika yang berbentuk soal cerita pada materi bangun ruang. Menurut Tambuna : 1999 (dalam Retna : 2013) soal cerita adalah suatu pertanyaan yang diuraikan dalam cerita bermakna yang dapat dipahami, dijawab secara matematis berdasarkan pengalaman belajar sebelumnya. Menurut Sutisna (2010) Soal cerita adalah uraian kalimat yang dituangkan dalam bahasa verbal yang menguraikan suatu masalah dan mengandung suatu pertanyaan yang harus dipecahkan. Berdasarkan uraian diatas dapat disimpulkan bahwa Soal Cerita merupakan soal yang disajikan dalam bentuk cerita bermakna yang berkaitan dengan kehidupan sehari-hari yang berdasarkan pada pengalaman belajar sebelumnya. Masalah bangun ruang yang digunakan dalam penelitian ini yaitu materi bangun ruang yang diajarkan dalam kelas VIII MTs yang disesuaikan dalam standar kompetensi berikut ini:

TABEL 2 Standar Kompetensi Dan Kompetensi Dasar Materi Bangun Ruang

\begin{tabular}{|l|l|}
\hline \multicolumn{1}{|c|}{ Standar Kompetensi } & \multicolumn{1}{c|}{ Kompetensi Dasar } \\
\hline $\begin{array}{l}\text { Memahami sifat-sifat kubus, } \\
\text { balok, prisma, limas dan bagian- } \\
\text { bagiannya, serta menentukan } \\
\text { ukurannya }\end{array}$ & $\begin{array}{l}\text { Menghitung luas permukaan dan volume } \\
\text { kubus, balok ,prisma dan limas. }\end{array}$ \\
\hline
\end{tabular}

Suparmin dan Sriono (2015)

Berdasarkan uraian diatas, rumusan masalah dalam penelitian ini adalah Bagaimana profil kemampuan pemecahan masalah berbentuk soal cerita siswa kelas VIII-B MTs Miftahul Ulum Magersari yang berkemampuan tinggi, sedang dan rendah pada materi bangun ruang? Sedangkan tujuan dari penelitian ini adalah untuk Mendeskripsikan profil kemampuan pemecahan masalah berbentuk soal cerita siswa kelas VIII-B MTs Miftahul Ulum Magersari yang berkemampuan tinggi, sedang dan rendah pada materi bangun ruang

\section{Metode Penelitian}

Penelitian ini merupakan penelitian deskriptif kualitatif dengan tujuan mendeskripsikan profil kemampuan pemecahan masalah berbentuk soal cerita siswa kelas VIII-B MTs Miftahul Ulum Magersari yang berkemampuan tinggi, sedang dan rendah pada materi bangun ruang. Subyek dalam penelitian ini adalah siswa kelas VIIIB MTs. Miftahul Ulum Magersari yang berjumlah 37 siswa. Sedangkan subyek yang akan dianalisis datanya dari hasil tes sebanyak 6 siswa yang dipilih dari 37 siswa. Dimana 6 siswa tersebut akan digolongkan dalam kategori diantaranya dua siswa berkemampuan tinggi, dua siswa berkemampuan sedang dan dua siswa berkemampuan rendah. Pemilihan subyek dilakukan dengan pemberian tes kemampuan matematika kepada 37 siswa yakni kelas VIII-B. kemudian diambil 6 siswa berdasarkan hasil tes kemampuan matematika dan hasil pertimbangan guru mata pelajaran matematika yaitu dengan memilih siswa yang dapat diwawancarai. Adapun keenam subyek tersebut adalah DF, PDH, AQA, FZS, RW dan NH. Prosedur penelitian yang dilakukan dalam penelitian ini terdiri dari 4 tahap yaitu: tahap persiapan, tahap pelaksanaan, tahap analisis data dan tahap penulisan laporan. Instrumen penelitian ini berupa tes kemampuan matematika, tes kemampuan pemecahan masalah matematika dan wawancara. Tes kemampuan matematika berisi tentang materi pelajaran matematika kelas VIII sedangkan tes kemampuan pemecahan masalah matematika berupa soal cerita materi bangun ruang. Untuk meyakinkan jawaban siswa maka dilakukan 
wawancara secara langsung berdasarkan jawaban yang telah ditulis. Untuk melakukan wawancara disusun pedoman wawancara. Pedoman wawancara dibuat secara terstruktur untuk menginvestigasi kemampuan pemecahan masalah siswa.

Teknik analisis data dalam penelitian ini sebagai berikut:

\subsection{Analisis Hasil Tes Kemampuan Matematika}

Analisis data skor siswa pada tes kemampuan matematika dilakukan dengan mengelompokkan siswa ke dalam tiga tingkat kemampuan matematika berdasarkan skor tes kemampuan siswa. Adapun pengelompokkan siswa dalam tiga kelompok tersebut berdasarkan tes kemampuan siswa dengan kriteria penilaian dalam tabel sebagai berikut:

TABEL 3 Kriteria Pengelompokkan Kemampuan Matematika Siswa

\begin{tabular}{|c|c|}
\hline Kelompok & Skor \\
\hline Kemampuan matematika rendah & $\mathbf{0} \leq \mathbf{x}<\mathbf{6 0}$ \\
\hline Kemampuan matematika sedang & $\mathbf{6 0} \leq \mathbf{x}<\mathbf{8 0}$ \\
\hline Kemampuan matematika tinggi & $\mathbf{8 0} \leq \mathbf{x} \leq \mathbf{1 0 0}$ \\
\hline
\end{tabular}

Abdillah dan Budiarto (2014)

\subsection{Analisis Data Hasil Tes Pemecahan Masalah}

Analisis data hasil tes kemampuan pemecahan masalah matematika berbentuk soal cerita siswa berdasarkan pada indikator pencapaian pemecahan masalah.yang telah dibuat.

TABEL 4 Indikator Pencapaian Kemampuan Pemecahan Masalah

\begin{tabular}{|c|c|c|}
\hline $\begin{array}{l}\text { Tahap Pemecahan } \\
\text { Masalah Oleh } \\
\text { Polya }\end{array}$ & Kategori & Indikator \\
\hline \multirow[t]{3}{*}{$\begin{array}{l}\text { Memahami } \\
\text { Masalah }\end{array}$} & Baik & $\begin{array}{l}\text { Siswa dapat menyebutkan informasi-informasi yang } \\
\text { diberikan dan pertanyaan yang diajukan dalam } \\
\text { masalah matematika berbentuk soal cerita }\end{array}$ \\
\hline & Cukup & $\begin{array}{l}\text { Siswa kurang lengkap dalam menyebutkan } \\
\text { informasi yang diberikan dan pertanyaan yang } \\
\text { diajukan dalam masalah matematika berbentuk soal } \\
\text { cerita }\end{array}$ \\
\hline & Kurang & $\begin{array}{l}\text { Siswa tidak dapat menyebutkan informasi yang } \\
\text { diberikan dan pertanyaan yang diajukan dalam } \\
\text { masalah matematika berbentuk soal cerita }\end{array}$ \\
\hline \multirow[t]{3}{*}{$\begin{array}{l}\text { Merencakan } \\
\text { Pemecahan }\end{array}$} & Baik & $\begin{array}{l}\text { Siswa memiliki rencana pemecahan masalah dan } \\
\text { rencana tersebut dapat membantunya dalam } \\
\text { memecahkan masalah matematika berbentuk soal } \\
\text { cerita }\end{array}$ \\
\hline & Cukup & $\begin{array}{l}\text { Siswa memiliki rencana pemecahan masalah dan } \\
\text { rencana tersebut kurang dapat membantunya dalam } \\
\text { memecahkan masalah matematika berbentuk soal } \\
\text { cerita }\end{array}$ \\
\hline & Kurang & $\begin{array}{l}\text { Siswa tidak memiliki rencana dalam memecahkan } \\
\text { masalah matematika berbentuk soal cerita }\end{array}$ \\
\hline Melakukan & Baik & Siswa dapat menjelaskan langkah pemecahan \\
\hline
\end{tabular}




\begin{tabular}{|c|c|c|}
\hline $\begin{array}{c}\text { Tahap Pemecahan } \\
\text { Masalah Oleh } \\
\text { Polya }\end{array}$ & Kategori & Indikator \\
\hline \multirow[t]{3}{*}{$\begin{array}{l}\text { Rencana } \\
\text { Pemecahan }\end{array}$} & & $\begin{array}{l}\text { masalah matematika berbentuk soal cerita yang } \\
\text { yang ia gunakan dengan hasil yang benar }\end{array}$ \\
\hline & Cukup & $\begin{array}{l}\text { Siswa dapat menjelaskan langkah pemecahan } \\
\text { masalah matematika berbentuk soal cerita yang } \\
\text { yang ia gunakan dengan hasil yang kurang benar }\end{array}$ \\
\hline & kurang & $\begin{array}{l}\text { Siswa tidak dapat menjelaskan langkah pemecahan } \\
\text { masalah matematika berbentuk soal cerita yang } \\
\text { yang ia gunakan dengan hasil yang salah }\end{array}$ \\
\hline \multirow[t]{3}{*}{$\begin{array}{l}\text { Memeriksa } \\
\text { Kembali } \\
\text { Pemecahan }\end{array}$} & Baik & $\begin{array}{l}\text { Siswa memeriksa kembali langkah pemecahan } \\
\text { masalah matematika berbentuk soal cerita yang ia } \\
\text { gunakan secara menyeluruh }\end{array}$ \\
\hline & Cukup & $\begin{array}{l}\text { Siswa memeriksa kembali langkah pemecahan } \\
\text { masalah matematika berbentuk soal cerita yang ia } \\
\text { gunakan hanya sebagian }\end{array}$ \\
\hline & Kurang & $\begin{array}{l}\text { Siswa tidak memeriksa kembali langkah pemecahan } \\
\text { masalah matematika berbentuk soal cerita yang ia } \\
\text { gunakan. }\end{array}$ \\
\hline
\end{tabular}

Nirmalitasari (2012)

\subsection{Wawancara}

Uji ini digunakan untuk menganalisis hasil wawancara siswa.. Analisis data kualitatif dilakukan tiga kegiatan secara bersamaan yaitu : (1) reduksi data, (2) penyajian data, dan (3) penarikan kesimpulan.

Hasil dari data yang diperoleh dalam kegiatan penelitian ini selanjutnya akan digabungkan dan disimpulkan serta diuji keabsahannya dengan cara: ketekunan pengamat, triangulasi dan pemeriksaan sejawat

\section{Hasil Penelitian dan Pembahasan}

Berdasarkan hasil penelitian dapat diperoleh profil kemampuan pemecahan masalah matematika siswa berbentuk soal cerita pada materi bangun ruang adalah sebagai berikut:

\subsection{Profil Kemampuan Pemecahan Masalah Matematika Subyek Berkemampuan Tinggi}

Berdasarkan hasil analisis jawaban tertulis dan wawancara oleh subyek DF dan PDH dapat digambarkan profil subyek dalam memecahkan masalah matematika berbentuk soal cerita yaitu: Pada soal nomor 1 dalam memahami masalah matematika yang berbentuk soal cerita subyek DF termasuk kategori baik sedangkan subyek PDH juga termasuk dalam kategori baik, dalam merencanakan pemecahan masalah matematika yang berbentuk soal cerita subyek DF termasuk kategori baik sedangkan subyek PDH juga termasuk dalam kategori baik, dalam melakukan rencana pemecahan masalah matematika yang berbentuk soal cerita subyek DF termasuk kategori baik sedangkan subyek PDH juga termasuk dalam kategori baik kategori baik, dan dalam memeriksa kembali pemecahan masalah matematika yang berbentuk soal cerita subyek DF termasuk kategori baik sedangkan subyek PDH juga termasuk dalam kategori baik. Pada soal nomor 2 dalam memahami masalah matematika yang berbentuk soal cerita 
subyek DF termasuk kategori baik sedangkan subyek PDH juga termasuk dalam kategori baik, dalam merencanakan pemecahan masalah matematika yang berbentuk soal cerita subyek DF termasuk kategori baik sedangkan subyek PDH juga termasuk dalam kategori baik, dalam melakukan rencana pemecahan masalah matematika yang berbentuk soal cerita subyek DF termasuk kategori baik sedangkan subyek PDH juga termasuk dalam kategori baik kategori baik, dan dalam memeriksa kembali pemecahan masalah matematika yang berbentuk soal cerita subyek DF termasuk kategori baik sedangkan subyek PDH juga termasuk dalam kategori baik. Pada soal nomor 3 dalam memahami masalah matematika yang berbentuk soal cerita subyek DF termasuk kategori baik sedangkan subyek PDH juga termasuk dalam kategori baik, dalam merencanakan pemecahan masalah matematika yang berbentuk soal cerita subyek DF termasuk kategori baik sedangkan subyek PDH juga termasuk dalam kategori baik, dalam melakukan rencana pemecahan masalah matematika yang berbentuk soal cerita subyek DF termasuk kategori baik sedangkan subyek PDH juga termasuk dalam kategori baik kategori baik, dan dalam memeriksa kembali pemecahan masalah matematika yang berbentuk soal cerita subyek DF termasuk kategori baik sedangkan subyek PDH juga termasuk dalam kategori baik. Pada soal nomor 4 dalam memahami masalah matematika yang berbentuk soal cerita subyek DF termasuk kategori baik sedangkan subyek PDH juga termasuk dalam kategori baik, dalam merencanakan pemecahan masalah matematika yang berbentuk soal cerita subyek DF termasuk kategori baik sedangkan subyek PDH juga termasuk dalam kategori baik, dalam melakukan rencana pemecahan masalah matematika yang berbentuk soal cerita subyek DF termasuk kategori baik sedangkan subyek PDH juga termasuk dalam kategori baik kategori baik, dan dalam memeriksa kembali pemecahan masalah matematika yang berbentuk soal cerita subyek DF termasuk kategori baik sedangkan subyek PDH juga termasuk dalam kategori baik. Pada soal nomor 5 dalam memahami masalah matematika yang berbentuk soal cerita subyek DF termasuk kategori baik sedangkan subyek PDH juga termasuk dalam kategori baik, dalam merencanakan pemecahan masalah matematika yang berbentuk soal cerita subyek DF termasuk kategori baik sedangkan subyek PDH juga termasuk dalam kategori baik, dalam melakukan rencana pemecahan masalah matematika yang berbentuk soal cerita subyek DF termasuk kategori baik sedangkan subyek PDH juga termasuk dalam kategori baik, dan dalam memeriksa kembali pemecahan masalah matematika yang berbentuk soal cerita subyek DF termasuk kategori baik sedangkan subyek PDH juga termasuk dalam kategori baik.

\subsection{Profil Kemampuan Pemecahan Masalah Matematika Subyek Berkemampuan Sedang}

Berdasarkan hasil analisis jawaban tertulis dan wawancara oleh subyek AQA dan FZS dapat digambarkan profil subyek dalam memecahkan masalah matematika berbentuk soal cerita yaitu: Pada soal nomor 1 dalam memahami masalah matematika yang berbentuk soal cerita subyek AQA termasuk kategori baik sedangkan subyek FZS juga termasuk dalam kategori baik, dalam merencanakan pemecahan masalah matematika yang berbentuk soal cerita subyek AQA termasuk kategori baik sedangkan subyek FZS juga termasuk dalam kategori baik, dalam melakukan rencana pemecahan masalah matematika yang berbentuk soal cerita subyek AQA termasuk kategori baik sedangkan subyek FZS juga termasuk dalam kategori baik kategori baik, dan dalam memeriksa kembali pemecahan masalah matematika yang berbentuk soal cerita subyek AQA termasuk kategori baik sedangkan subyek FZS juga termasuk dalam kategori baik. Pada soal nomor 2 dalam memahami masalah matematika yang berbentuk soal cerita subyek AQA termasuk kategori cukup sedangkan subyek FZS juga termasuk dalam kategori baik, dalam merencanakan pemecahan masalah matematika yang berbentuk 
soal cerita subyek AQA termasuk kategori baik sedangkan subyek FZS juga termasuk dalam kategori baik, dalam melakukan rencana pemecahan masalah matematika yang berbentuk soal cerita subyek AQA termasuk kategori cukup sedangkan subyek FZS juga termasuk dalam kategori baik kategori cukup, dan dalam memeriksa kembali pemecahan masalah matematika yang berbentuk soal cerita subyek AQA termasuk kategori baik sedangkan subyek FZS juga termasuk dalam kategori baik. Pada soal nomor 3 dalam memahami masalah matematika yang berbentuk soal cerita subyek AQA termasuk kategori baik sedangkan subyek FZS juga termasuk dalam kategori baik, dalam merencanakan pemecahan masalah matematika yang berbentuk soal cerita subyek AQA termasuk kategori baik sedangkan subyek FZS juga termasuk dalam kategori baik, dalam melakukan rencana pemecahan masalah matematika yang berbentuk soal cerita subyek AQA termasuk kategori baik sedangkan subyek FZS juga termasuk dalam kategori baik kategori baik, dan dalam memeriksa kembali pemecahan masalah matematika yang berbentuk soal cerita subyek AQA termasuk kategori baik sedangkan subyek FZS juga termasuk dalam kategori baik. Pada soal nomor 4 dalam memahami masalah matematika yang berbentuk soal cerita subyek AQA termasuk kategori baik sedangkan subyek FZS juga termasuk dalam kategori baik, dalam merencanakan pemecahan masalah matematika yang berbentuk soal cerita subyek AQA termasuk kategori cukup sedangkan subyek FZS juga termasuk dalam kategori cukup, dalam melakukan rencana pemecahan masalah matematika yang berbentuk soal cerita subyek AQA termasuk kategori cukup sedangkan subyek FZS juga termasuk dalam kategori baik kategori cukup, dan dalam memeriksa kembali pemecahan masalah matematika yang berbentuk soal cerita subyek AQA termasuk kategori baik sedangkan subyek FZS juga termasuk dalam kategori baik. Pada soal nomor 5 dalam memahami masalah matematika yang berbentuk soal cerita subyek AQA termasuk kategori baik sedangkan subyek FZS juga termasuk dalam kategori baik, dalam merencanakan pemecahan masalah matematika yang berbentuk soal cerita subyek AQA termasuk kategori baik sedangkan subyek FZS juga termasuk dalam kategori baik, dalam melakukan rencana pemecahan masalah matematika yang berbentuk soal cerita subyek AQA termasuk kategori baik sedangkan subyek FZS juga termasuk dalam kategori baik, dan dalam memeriksa kembali pemecahan masalah matematika yang berbentuk soal cerita subyek AQA termasuk kategori baik sedangkan subyek FZS juga termasuk dalam kategori baik.

\subsection{Profil Kemampuan Pemecahan Masalah Matematika Subyek berkemampuan Rendah}

Berdasarkan hasil analisis jawaban tertulis dan wawancara oleh subyek RW dan NH dapat digambarkan profil subyek dalam memecahkan masalah matematika berbentuk soal cerita yaitu: Pada soal nomor 1 dalam memahami masalah matematika yang berbentuk soal cerita subyek RW termasuk kategori cukup sedangkan subyek NH juga termasuk dalam kategori cukup, dalam merencanakan pemecahan masalah matematika yang berbentuk soal cerita subyek RW termasuk kategori baik sedangkan subyek NH juga termasuk dalam kategori baik, dalam melakukan rencana pemecahan masalah matematika yang berbentuk soal cerita subyek RW termasuk kategori baik sedangkan subyek NH juga termasuk dalam kategori baik kategori baik, dan dalam memeriksa kembali pemecahan masalah matematika yang berbentuk soal cerita subyek RW termasuk kategori baik sedangkan subyek NH juga termasuk dalam kategori baik. Pada soal nomor 2 dalam memahami masalah matematika yang berbentuk soal cerita subyek RW termasuk kategori cukup sedangkan subyek NH juga termasuk dalam kategori cukup, dalam merencanakan pemecahan masalah matematika yang berbentuk 
soal cerita subyek RW termasuk kategori cukup sedangkan subyek NH juga termasuk dalam kategori baik, dalam melakukan rencana pemecahan masalah matematika yang berbentuk soal cerita subyek RW termasuk kategori cukup sedangkan subyek NH juga termasuk dalam kategori baik kategori cukup, dan dalam memeriksa kembali pemecahan masalah matematika yang berbentuk soal cerita subyek RW termasuk kategori baik sedangkan subyek NH juga termasuk dalam kategori baik. Pada soal nomor 3 dalam memahami masalah matematika yang berbentuk soal cerita subyek RW termasuk kategori baik sedangkan subyek NH juga termasuk dalam kategori baik, dalam merencanakan pemecahan masalah matematika yang berbentuk soal cerita subyek RW termasuk kategori baik sedangkan subyek NH juga termasuk dalam kategori baik, dalam melakukan rencana pemecahan masalah matematika yang berbentuk soal cerita subyek RW termasuk kategori baik sedangkan subyek NH juga termasuk dalam kategori baik kategori baik, dan dalam memeriksa kembali pemecahan masalah matematika yang berbentuk soal cerita subyek RW termasuk kategori baik sedangkan subyek NH juga termasuk dalam kategori baik. Pada soal nomor 4 dalam memahami masalah matematika yang berbentuk soal cerita subyek RW termasuk kategori baik sedangkan subyek NH termasuk dalam kategori kurang, dalam merencanakan pemecahan masalah matematika yang berbentuk soal cerita subyek RW termasuk kategori kurang sedangkan subyek NH juga termasuk dalam kategori cukup, dalam melakukan rencana pemecahan masalah matematika yang berbentuk soal cerita subyek RW termasuk kategori kurang sedangkan subyek NH juga termasuk dalam kategori baik kategori kurang, dan dalam memeriksa kembali pemecahan masalah matematika yang berbentuk soal cerita subyek RW termasuk kategori baik sedangkan subyek NH juga termasuk dalam kategori kurang. Pada soal nomor 5 dalam memahami masalah matematika yang berbentuk soal cerita subyek RW termasuk kategori cukup sedangkan subyek NH termasuk dalam kategori cukup, dalam merencanakan pemecahan masalah matematika yang berbentuk soal cerita subyek RW termasuk kategori cukup sedangkan subyek $\mathrm{NH}$ juga termasuk dalam kategori cukup, dalam melakukan rencana pemecahan masalah matematika yang berbentuk soal cerita subyek RW termasuk kategori baik sedangkan subyek NH termasuk dalam kategori cukup, dan dalam memeriksa kembali pemecahan masalah matematika yang berbentuk soal cerita subyek RW termasuk kategori baik sedangkan subyek NH juga termasuk dalam kategori baik

\section{Kesimpulan}

\subsection{Profil Kemampuan Pemecahan Masalah Matematika Subyek Berkemampuan Tinggi}

Dalam memahami masalah, kedua subyek termasuk dalam kategori baik. Dalam merencanakan pemecahan masalah, kedua subyek termasuk dalam kategori baik. Dalam melakukan rencana pemecahan masalah, kedua subyek termasuk dalam kategori baik. Dan dalam memeriksa kembali kedua subyek termasuk dalam kategori baik.

\subsection{Profil Kemampuan Pemecahan Masalah Matematika Subyek Berkemampuan Sedang}

Dalam memahami masalah, kedua subyek termasuk dalam kategori baik. Dalam merencanakan pemecahan masalah, kedua subyek termasuk dalam kategori cukup. Dalam melakukan rencana pemecahan masalah, kedua subyek termasuk dalam kategori cukup. Dalam memeriksa kembali kedua subyek termasuk dalam kategori baik. 


\subsection{Profil Kemampuan Pemecahan Masalah Matematika Subyek Berkemampuan Rendah}

Dalam memahami masalah, kedua subyek termasuk dalam kategori baik. Dalam merencanakan pemecahan masalah, kedua subyek termasuk dalam kategori cukup dan kurang. Dalam melakukan rencana pemecahan masalah, kedua subyek termasuk dalam kategori cukup dan kurang. Dalam memeriksa kembali kedua subyek termasuk dalam kategori baik.

\section{UcapanTerima Kasih}

Pada kesempatan ini penulis sampaikan terima kasih kepada berbagai pihak yang telah mendukung dalam penulisan makalah ini, diantaranya:

1. Rektor Universitas PGRI Ronggolawe (UNIROW) beserta jajarannya.

2. Teman-teman di Prodi Pend. Matematika FKIP UNIROW Tuban.

3. Kepala Sekolah, staf guru dan TU di MTs Miftahul Ulum Magersari.

4. Semua pihak yang telah memberikan bantuan baik langsung maupun tidak langsung dalam penulisan makalah ini.

\section{Daftar Pustaka}

[1] Abdillah, Fahmi dan Budiarto, Mega Teguh. 2014. Profil Kemampuan Penalaran Pada Siswa Dalam Memecahkan Masalah Kontekstual Berdasarkan Tingkat Kemampuan Matematika. (Online), Vol. 3 No. 1 (http://ejournal.unesa.ac.id/index.php/mathedunesa/article.pdf diakses 9 Maret 2016).

[2] Anisa, Witri N. 2014. Peningkatan Kemampuan Pemecahan Masalah Dan Komunikasi Matematik Melalui Pembelajaran Pendidikan Matematika Realistic Untuk Siswa SMP Negeri Di Kabupaten Garut. (Online) Vol.1 No. 1 (http://pasca.ut.ac.id/journal/index.php/JPK/article/download/12/12 diakses 9 maret 2016).

[3] Nirmalitasari, Octa S. 2012. Profil Kemampuan Siswa Dalam Memecahkan Masalah Matematika Berbentuk Open Start Pada Materi Bangun Ruang. (Online) Vol. 1 No. 1, (http://ejournal.unesa.ac.id/article/398/30/article.pdf, diakses 9 Maret 2016).

[4] Retna, M, Mubarokah, L dan Suhartik. 2013. Proses Berpikir Siswa Dalam Menyelesaikan Soal Cerita Ditinjau Berdasarkan Kemampuan Matematika. (Online) Vol.1 No.2, (http://lppm.stkippgri-sidoarjo.ac.id diakses 9 maret 2016).

[5] Rofiqoh, Zeni 2015. Analisis Kemampuan Pemecahan Masalah Matematika Siswa Kelas X Dalam Pemebelajaran Discorvery Learning Berdasarkangaya Belajar Siswa. Skripsi. FMIPA . Pendidikan Matematika (Online) (http://lib.unnes.ac.id/22322/1/4101411053-s.pdf diakses 9 maret 2016)

[6 ]Saepuloh, Asep Rahmat.2013.Penerapan Model Pembelajaran Sinektik Untuk Meningkatkan Kemampuan Representasi Dan Komunikasi Matematis Siswa SMP. Tesis. Pendidikan Matematika (Online). (http://repository.upi.edu/517/1/T-MTK-1102555/TING.pdf diakses 9 Maret 2016).

[7] Sahrudin, Asep. 2016 .Implementasi Model Pembelajaran Means-Ends Analysis Untuk Meningkatkan Kemampuan Pemecahan Masalah Matematika Mahasiswa.

(Online),

Vol.4

No.1 
Profil Kemampuan Pemecahan Masalah Matematika Siswa Berbentuk Soal Cerita Materi Bangun Ruang

(http://journal.unsika.ac.id/index.php/judika/article/download/233/2 diakses 5 mei 2016).

[8] Sumardyono. 2010. Pengertian Dasar Problem Solving. Makalah (Online) (http://p4tkmatematika.org/file/problemsolving/pengertiandasarproblemsolving .pdf diakses 10 Mei 2015)

[9] Suparmin dan Sriono. 2015. Matematika untuk SMP/MTs. Surakarta: Suara Media Sejahtera.

[10] Sutisna. 2010 Analisis Kesulitan Menyelesaikan Soal Cerita Matematika Pada Siswa Kelas IV MI YAPIA. (Online) (http://repository.uinjkt.ac.id/dspace/bitstream/123456789/1/SUTISNAFITK.pdf diakses 5 mei 2016) 